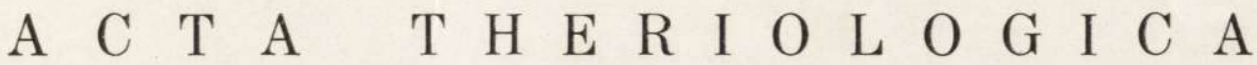

VOL. XVII, 17: 221-243.

BIAŁOWIEŻA

August, 1972

Anna B U C H A L C Z Y K

\section{Seasonal Variations in the Activity of Shrews}

[With 8 Tables \& 3 Figs.]

\begin{abstract}
Studies were made of the activity of shrews caught in the field and kept in cages outdoors (48 individuals of Sorex araneus, 5 of S. minutus, 2 of Neomys anomalus and 6 of $N$. fodiens) and also indoors (32 individuals of $S$. araneus). Distinction was made between locomotor activity measured by the number of times the animal emerged from the nest into the run, and feeding activity measured by the number of times the animal entered the feeding box during the day. Young adult shrews exhibit $83 \%$ more locomotor activity in summer than old adults, with feeding activity on a uniform level in both age groups. In autumn the animals' activity decreases, and this decrease becomes greater in winter. In spring there is an abrupt increase in activity. In summer the old adults' activity remains on the spring level, or increases very slightly. The differences between the average sum totals of daily activity for $S$. araneus at different seasons of the year are statistically significant, except for the differences between the level of old adults' activity in spring and summer. Variations in the activity of $S$. araneus kept indoors takes a similar course to that out of doors. In summer young adult males of $S$. araneus have higher daily activity than young adult females and old adults of both sexes, and are more active during the night hours than the other groups. The daily activity pattern varies depending on the season. In summer and spring it exhibits one peak, with intensified activity at night. In autumn and winter the level of activity for the day hours rises and the pattern exhibits at least two peaks. In the case of $S$. minutus intensified activity is observed during the day hours in spring also.
\end{abstract}

\section{INTRODUCTION}

Activity reflects changes taking place in animal organisms and expresses the way in which they expend their energy. Locomotor activity, which forms one of the elements of total activity, is a measure of the mobility of the given species, while feeding activity provides information as to frequency of feeding. Both these kinds of activity are parti- 
cularly interesting in shrews, mammals with extremely small body size and high energy requirements.

Studies on the activity of Soricidae, chiefly Sorex araneus, were carried out both indoors and outdoors, the study method employed ranging from direct visual observations ( $\mathrm{Cr}$ ow $\mathrm{cr}$ oft, 1959), recording daily activity in an apparatus ( $\mathrm{T} \mathrm{upikova,1949;}$ Crowcroft, 1954) to defining circadian activity patterns on the basis of daily oxygen consumption rhythm (G ę bczyński, 1965; 1971). The daily activity rhythm was also studied under natural conditions on the basis of the number of captures at different times of the day from April to October (J a nský \& Hanák, 1960). Studies mentioned above (excluding those made by Gę bc z yńcki, 1965), did not however cover the whole yearly cycle and were not usually based on material segregated according to age an sex. Such segregation is essential on account of the specific age and seasonal changes found in shrews (cf. P u c e k, 1970).

The purpose of the present study was to obtain the most extensive data possible of shrews' activity at different times of the year.

\section{MATERIAL AND METHODS}

Observations of shrews' daily activity rhythm were made from November 24th 1965 to October 31st, 1966 in all seasons of the year. The studies covered a total of 40 individuals of Sorex araneus $\mathrm{L}$ inn a e us, 1758, this figure including 26 old adults (9 females and 17 males) and 14 young adults ( 8 females, 3 males, 3 sex indet.). As the material from the winter season was very scanty, additional observations were made of two males and one female from February 20th - March 5 th, 1971. The data obtained were allocated to the transitional period between winter and spring - the pre-spring period, as both the recorded activity level and daily activity pattern differed markedly from the winter observations and were similar to those obtained in spring.

Additional observations (not covering all seasons) were made of 5 old adults of Sorex minutus Linnaeus, 1766; 5 old adults and 1 young adult individual of Neomys fodiens (Pennant, 1771) and 1 old adult and 1 young adult individual of Neomys anomalus $\mathrm{C}$ abrer a, 1907, and the results included here. All the animals were obtained from the Białowieża National Park. The studies were carried out under semi-natural conditions, i.e. in cages situated outdoors, containing animals fed a standard diet.

During the experiment and beforehand the animals were kept separately in wooden cages divided into a nest $(15 \times 15 \mathrm{~cm})$, run $(15 \times 40 \mathrm{~cm})$ and feeding compartment $(15 \times 10 \mathrm{~cm})$. The nest was separated from the run by a short corridor preventing passage being blocked by nest material (Fig. 1a). The roof of the nest was wooden, and that of the run metal wire netting. The roof of the feeding box and its front wall were made of glass. Dry leaves and moss was provided as nest material, and sawdust used as litter. Both the litter and nest were usually changed once a week. The cages, joined to form units of five, were placed in a wooden case with a glass front, and additional protection was provided by an open shed. When 
air temperature fell below zero the case was covered with straw matting, which maintained a higher temperature inside than the ambient temperature outside. Minimum air temperature inside the case was similar to those given for the forest litter under the snow cover (cf. Coulianos \& Johnels, 1962) and only exceptionally was below freezing point, e.g. from 24.11 .1965 to 10.12 .65 for four days it fell to $-3^{\circ}--6^{\circ} \mathrm{C}$, and from $14-28$. Feb. 1966 for five days from $-1^{\circ}--2,5^{\circ} \mathrm{C}$. Its amplitude was also smaller than outside the case.

Standard diet (a mixture of minced liver, heart, kidneys, spleen, all without fat, with added sprouting wheat) and water was fed once daily ad libitum, about 8.30 a.m.

The animals' passage was recorded on the tape of a Jacquet polygraph. The contacts were located in the passage from the corridor leading from the nest to the run and from the run to the feeding box (Fig. 1a). In this way a record was

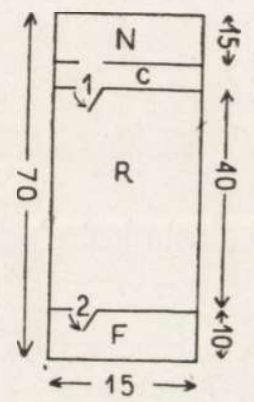

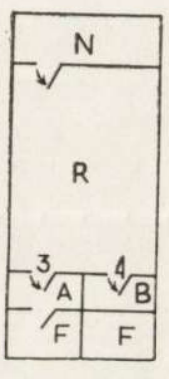

Fig. 1. Plan of cages used during the experiments in 1965-1966, 1971 (a) and 1963-1964 (b) years. Dimensions of cages in $\mathrm{cm}$.

$\mathrm{N}$ - nest; $\mathrm{C}$ - corridor in front of nest; $\mathrm{R}$ - run; $\mathrm{F}$ - feeding box; $\mathrm{A}$ - part of corridor leading to feeding box containing food; B - part of corridor leading to enclosed part of feeding box without food; $1,2,3,4-$ passages with counters recording transits.

kept of the number of exits from the nest, which gave locomotor activity, and the number of entries to the feeding box - which gave feeding activity.

Unelaborated data obtained in other experiments from 1963-1964 ( $\mathrm{J}$. H e jwow$\mathrm{sk}$ a, unpubl. data) were also used for the purposes of this study. The aim of those experiments was to study the learning ability of shrews but at the same time their activity was recorded. A total of 37 individuals of $S$. araneus were observed in these experiments indoors and outdoors.

The times and conditions of the plearning experiments « were given in table 1. The captured animals were kept separately for three days in a standard rearing cage for shrews, then transferred to the experimental cage (Fig. 1b) and recording of activity started. In the experiments $1-4$ (Table 1) the number of entries through contact A were recorded as wcorrect entries, and through B as sincorrect ones. Passages between the run and feeding box were treated as locomotor activity. 
regardless of whether they were scorrect " or »incorrect«. Feeding activity was based only on sum totals of correct transits per day, i.e. only to the part of feeding box containing food.

In experiments 5-8 (Table 1) the contacts were situated respectively on the passage from the nest into the run, and from the run into the feeding box. Passage was registered on kymograph tape, which later made it possible to establish the

Table 1

Dates and conditions of experiments on the activity of $S$. araneus in 1963 and 1964 years.

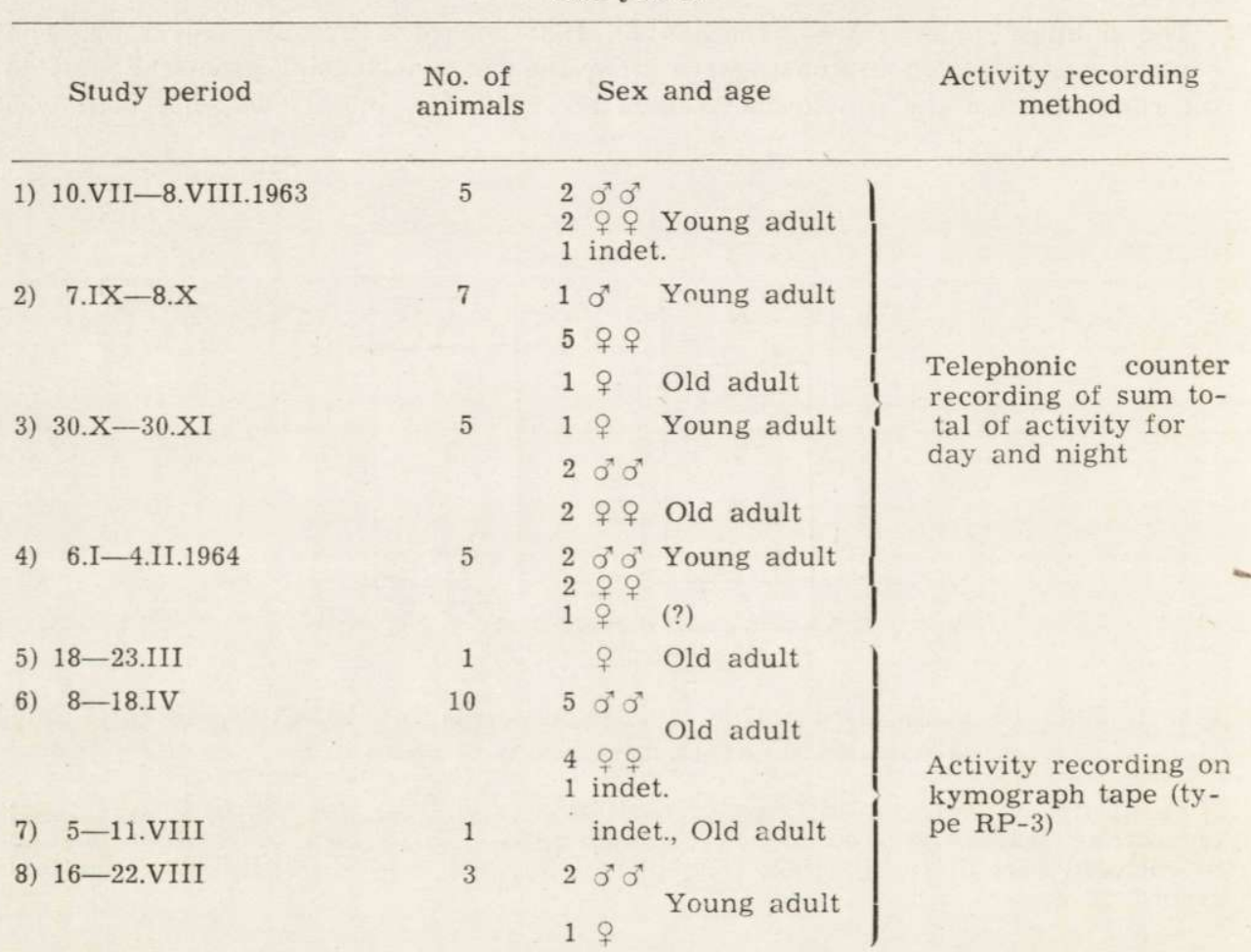

Experiments carried out under semi-natural conditions »outdoors (No, 5, 7 and 8) and "indoors (No. $1-4$ and 6). Indoor conditions: Temperature approx. $18^{\circ} \mathrm{C}$ Daylinght supplemented by artificial lighting (day : night=12 : 12 hours). Wooden cage divided into nest, run, corridor and feeding box. Standard food with addition of sprouting wheat and yeast, ad libitum, offered regularly twice daily, morning and evening. In experiments 7 and 8 feeding times were not constant. Outdoor conditions: Only part A of corridor and feeding box used. Feeding as in experiment $1-5$.

daily distribution of locomotor activity (experiments $5,7,8$ ) or both types of activity (experiment 6). Endeavour was made not to disturb the animals during the experiment: the nest was cleaned out after the experiment, records kept of the time of cleaning the feeding box; the animals were weighed, with the exception of experiments $1-4$, only before and after the end of the experiment. 
The material accumulated in this way is extensive in respect to the number of observations of daily activity, but does not cover all age groups of shrews. In summer, for instance, the only observations were made of young adult animals (Table 2).

Locomotor and feeding activity were treated separately in calculations, and statistical calculations made using the t-Student test.

\section{SEASONAL AND AGE VARIATION IN THE DAILY ACTIVITY OF}

\section{S. ARANEUS}

Sorex araneus exhibits relatively high activity through the whole of the 24-hour period. The level of activity observed outdoors fluctuates over the year and average sum totals of both feeding and locomotor activity depend on the season.

In young adult individuals, in summer, both kinds of activity are maintained on a relatively high level, locorotor activity being about twice higher than feeding activity. In autumn the animals' activity decreases. Over the whole yearly cycle the lowest level of average daily activity is observed during winter. In spring there is an abrupt increase in activity which continues on this level in summer (Table 2, Fig. 2) in the case of old adults. It must be emphasised that in respect of feeding activity its average values in young adults and old adults from summer do not differ, although the locomotor activity of young adults shrews during this season is $\mathbf{8 3} \%$ higher than that of old adults (Table 3 ). Differences in the values of the average sum totals of daily activity between different seasons of the year, outdoors, are statistically significant (in all cases $\mathrm{P}<0.05$ ), except the difference between the activity for spring and summer.

A similar pattern of variation in the shrews' activity during the year is also observed in individuals caught in the field and brought to relatively constant laboratory conditions. In summer locomotor activity is high, but decreases in autumn and reaches an even lower level in winter (Table 2). Data on feeding activity also indicate that similar variation occurs to those found outdoors (cf. also Fig. 2 - data for individuals from spring). Shrews observed in cages indoors, three days after their capture exhibit activity appropriate to the season, although the average level of both types of activity is higher than outdoors, this being particularly distinct in winter (Table 2).

The decrease in activity of shrews kept outdoors in winter and its increase in spring would appear to be connected to a great extent with the animals' age and physiological condition. This is borne out by the results of observations made in the early spring period of 1971 of two males and one female (Table 2 - data for pre-spring period). The 
average daily locomotor activity of these shrews is higher than in winter but lower (difference statistically significant, $\mathrm{P}<0.001$ ) than the values obtained for the spring of 1966 .

As great activity in spring is characteristic of sexually mature individuals the increase in the activity level of shrews in pre-spring can be explained by the onset of sexual maturation. Animals were caught during a very mild winter and when dissected were found to exhibit slight enlargement of the gonads in relation to the picture usually observed under winter conditions. The feeding activity of these shrews was also high. A similarly high level of both types of activity was observed in

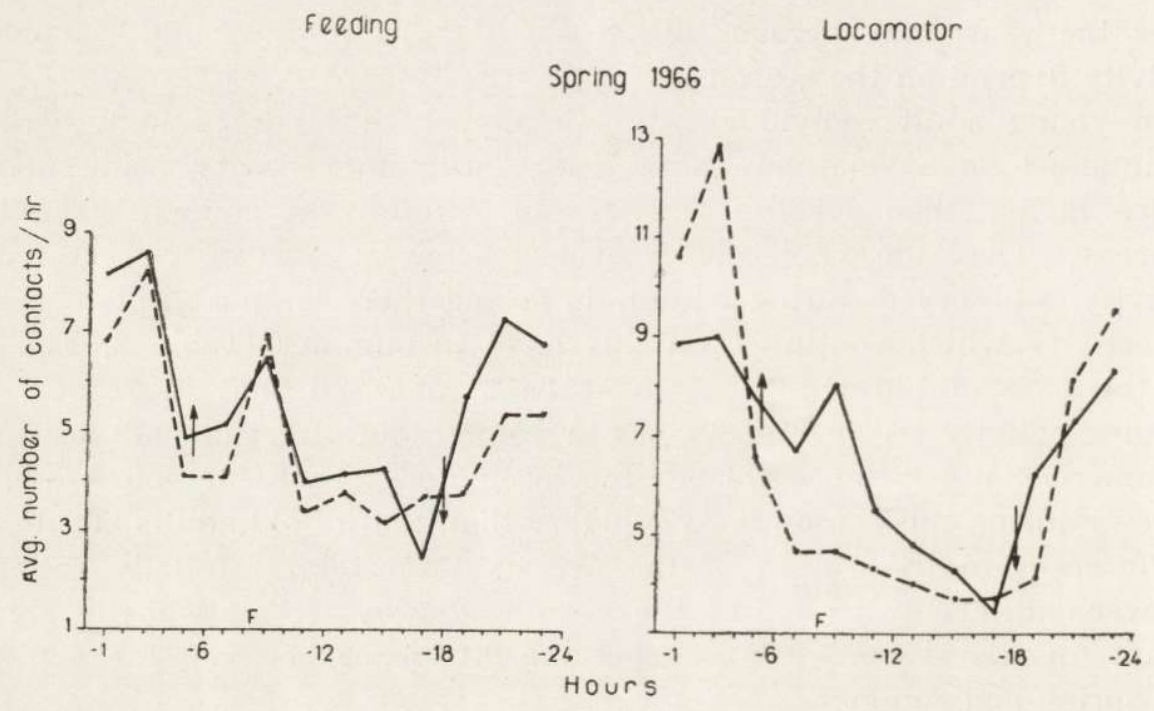

Fig. 2. Daily activity patterns for $S$, araneus under outdoor conditions. Continued on page 227.

$\mathrm{F}$ - feeding time; Arrows indicate sunrise and sunset.

In summer pattern of shrews' activity the solid line shows the activity of old adults; the broken line - of young adults and the doted one - the activity of both age groups jointly.

In spring pattern of daily activity the broken line shows the activity of ten individuals under indoor conditions, during period from April 8th to 18th, 1964.

one female at the end of February 1966. Young adult females also exhibited increase in feeding activity in the winter 1966 comparing with the autumn, but these differences were not statistically significant $(0.1>\mathrm{P}>0.05)$.

Locomotor and feeding activity at different times of the year also depends partly on the sex of the individuals observed. The summer data obtained outdoors enable this phenomenon to be discussed and statistically evaluated. Even with a relatively small number of animals large numbers of exits and entrances were obtained per day (in one case 


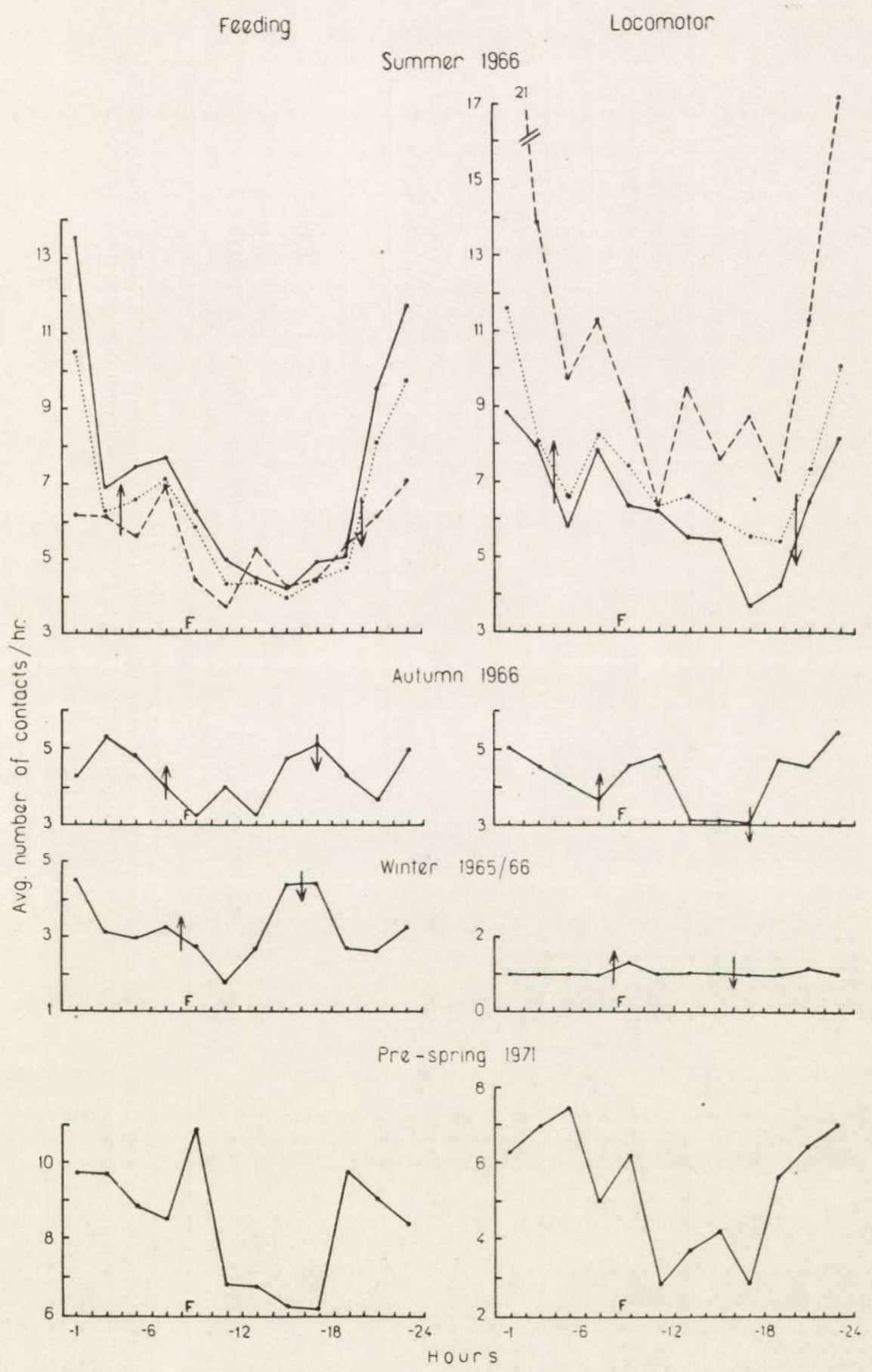

Fig. 2. (Continued). 


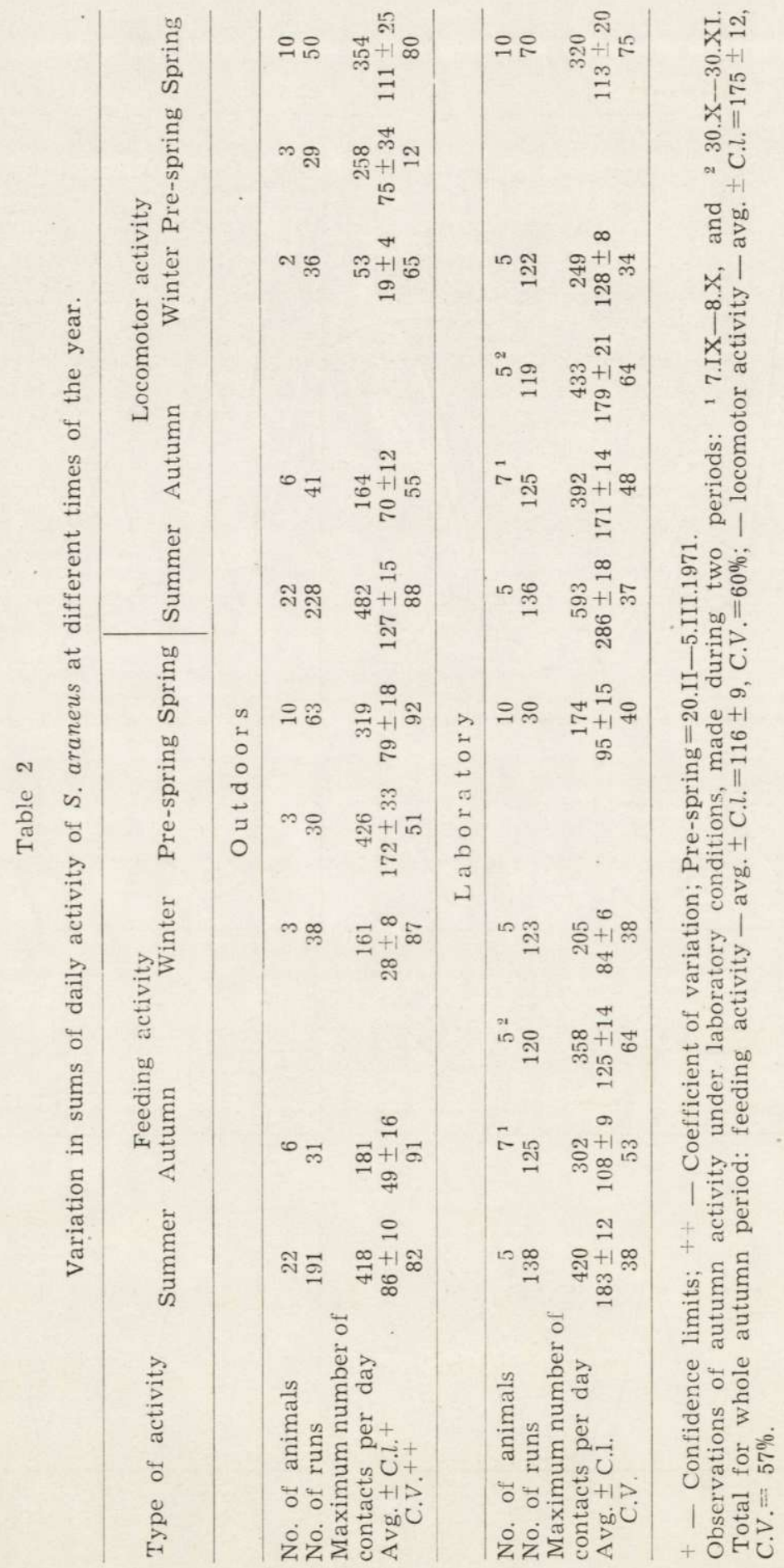




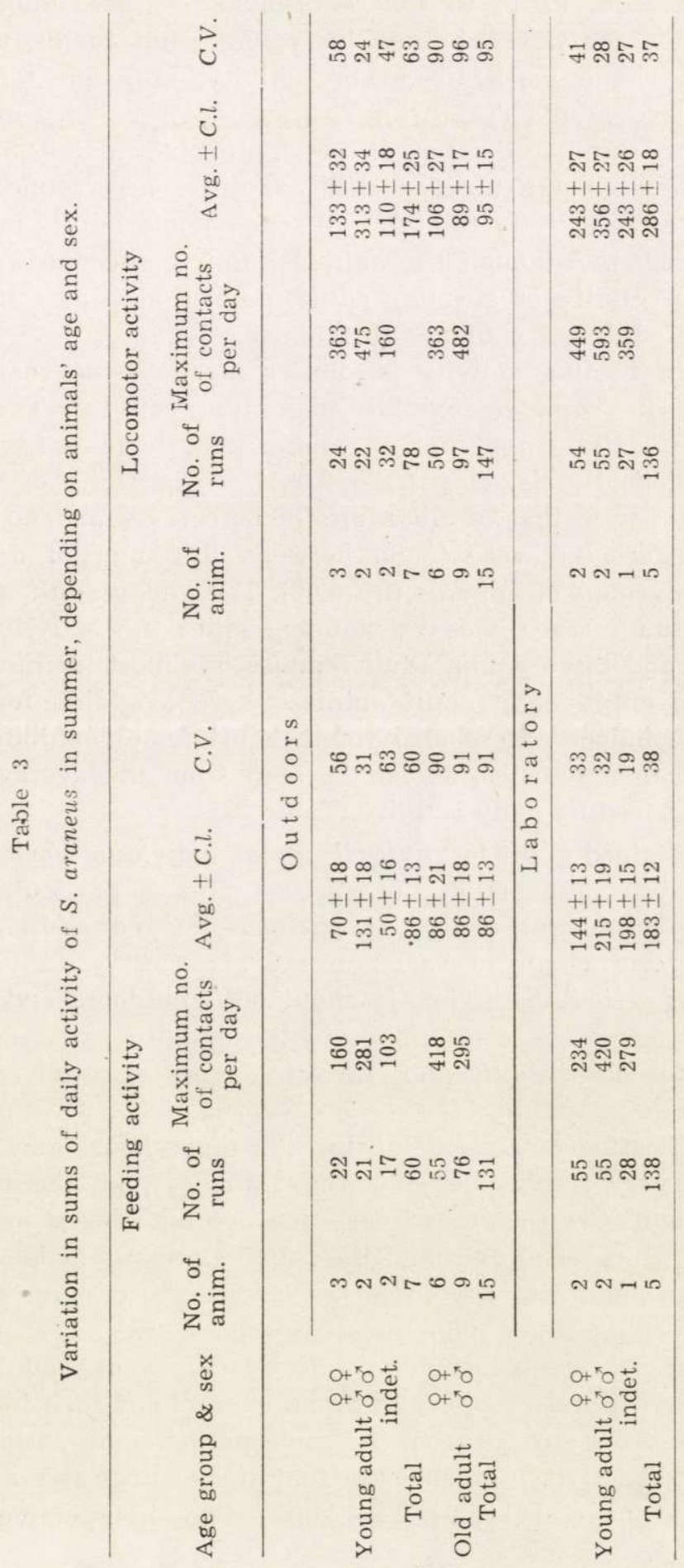


only 17 , and from 21 to 97 for the remainder). Maximum locomotor activity in summer was exhibited by young adult males, while young adult females have markedly lower activity, although this is higher than that of old adults (Table 3). The locomotor activity of old adults for spring and summer did not differ significantly $(P>0.05)$ from each other; neither were statistically significant differences found in the sum totals of the daily activity for the two sexes of old adults in spring and summer $(\mathrm{P}>0.05)$. Although the animals' activity decreases in autumn, here also the activity of a young adult male is high as compared with that of an old adult and young adult females.

Variation in feeding activity is similar in the same seasons. Young adult males in summer exhibit maximum activity. The difference between their activity and that of young adult females from the same period is statistically significant $(\mathrm{P}<0.001)$. The activity of young adult females is similar to that of old adults of both sexes and no statistically significant differences were found between the sums of daily activity for these two groups of animals $(\mathrm{P}>0.05)$. The young adult male is most active in autumn, as it was previously, while the activity of an old adult female and three young adult females is almost identical.

In summer only young adult animals were available for the experiments made indoors. Here also young adult males exhibited a higher activity level than females, as can be seen from the average values of locomotor and feeding daily activity (Table 3 ).

The data obtained point to unusually great individual variation in both locomotor and feeding activity of shrews. This is particularly marked during the reproduction season in the case of old adults, when, for instance, the coefficients of variation are about $90 \%$. In young adults for this same period the figure is about $60 \%$ outdoors and about $40 \%$ e indoors. This difference also applies to the activity pattern. Individuals were encountered with extremely differing types of activity, e.g. among old adult males in summer there were very active individuals with distinct intensification of activity during the night hours and others with a generally lower activity level, without any distinct intensification of activity at night. Coefficients of variation are high, even in the case of large amount of material used and the relatively constant laboratory conditions [cf. locomotor activity in spring C.V.- $75 \%$ or numerous runs in autumn of feeding (C.V. $=60 \%$ ) and locomotor (C.V. $=57 \%$ ) activities]. The record of very high locomotor activity of a young adult female in summer 1964 would also appear to be an example of such individual variation. Three other shrews from the same period come within the range of this type of activity for shrews from the analogical season of 1966 (experiment 7 and 8 , Table 1). This shows that, irrespective of the un- 
doubted effect of the study method itself, variation in individual activity on so wide a scale is characteristic of shrews.

\section{DAILY ACTIVITY RHYTHM OF S. ARANEUS}

Shrews are active for the whole of 24-hour period, without exhibiting the long resting periods so characteristic of small rodents. Increase in activity during the day varies, however, according to season. The daily rhythm of locomotor and feeding activity is generally similar in pattern but there are also some differences observed.

In summer, when there is distinct intensification of activity during the night hours, young adult shrews also exhibit considerable locomotor activity during the daytime and two peaks of activity are observed in the second half of this period: the first, and higher, about 1 p.m. and the second, slightly lower, about 5 p.m. In autumn the daily activity pattern exhibits two peaks: the higher peak occurs in the evening (about $8-12$ p.m.) the lower during the day ((about $10-12$ a.m.). In winter, locomotor activity is distributed almost evenly over the 24 hours, with a slight increase in activity during the day. In pre-spring a distinct change is again observed in this pattern. Intensified activity occurs during the night hours, but a small peak is also observed during the day at about 3 p.m. (Fig. 2). Spring activity has only one peak. Increased activity occurs between 6 p.m. (sundown) and 3 a.m. In summer, activity pattern of old adults has only one peak, which occurs about midnight, and the greatest decrease in activity is observed about 5 p.m. Dawn, and even more so dusk, are key points in the animals' activity, this being particularly distinct in spring and summer. At dawn there is a periodical decrease, and after sunset - a distinct increase in activity level (Fig. 2). The activity pattern described is also exhibited by shrews caught in the field in spring and transferred to indoor conditions. Under the latter conditions the increase in activity during the night hours is even more clearly marked than that observed outdoors (Fig. 2 data for spring).

The feeding activity pattern is similar in the different seasons of the year, but in autumn and winter activity during the daytime hours increases more markedly than it is observed for locomotor activity. The winter pattern has two peaks, with the higher peak between $2-6$ p.m. and lower about 1 a.m. As many as three peaks can be distinguished in autumn activity, which do not differ greatly as to level: about 3 a.m., between 3-6 p.m. and about midnight. There is a slight increase in activity during the day, about 11 a.m. (Fig. 2). The pattern of feeding activity of young adults and old adults in summer do not differ apart 
from the slight increase in activity about 1 p.m. in young adult shrews (Fig. 2).

Feeding of animals at a fixed hour results in increased activity of particular individuals, often to a considerable extent (cf. Fig. 2). This peak was not taken into consideration in discussing the daily activity rhythms, as it was the consequence of the accepted experimental conditions. In seasons in which there was considerable increase in activity in the night or daytime hours, an increase in the activity of the animals was observed even in the period preceding feeding time (Fig. $2-$ cf. activity patterns for summer and feeding activity for winter).

In order to illustrate the daily amplitude of the shrews' activity over the whole year calculation was made of increase in activity between minimum and maximum level (Table 4). The amplitude of locomotor

\section{Table 4}

\begin{tabular}{l} 
Amplitude of daily activity of $S$. ara- \\
neus in different seasons of the year, \\
expressed in difference between mi- \\
nimum and maximum average number \\
of contacts during $24-$ hour period, per \\
hour, in percentages. Minimum activity \\
level $=100 \%$. \\
\hline \\
Season \\
Fummer
\end{tabular}

activity is greatest in individuals entering into reproduction (pre-spring and spring), and is about $40 \%$ lower in summer and the lowest in winter. The amplitude of activity in spring is about five times greater than in winter. Similarly feeding activity exhibits maximum amplitude in spring. Almost uniform amplitude is found for feeding activity in winter and summer and for the two transitional seasons (pre-spring, autumn). Both winter and summer amplitudes of activity are about twice greater than that for the other two seasons. Under indoor conditions in spring the shrews exhibited particularly wide ranges of locomotor activity, with amplitude in the case of feeding activity the same as that in shrews kept outdoors in summer.

Despite the fact that the common shrew is active over the whole of the 24-hour period, it is more a nocturnal than diurnal animal (Table 5). 
In the autumn-winter season daytime activity increases. In seasons in which the shrews' activity intensifies at night the ratio of day to night activity is $0.5-0.6$, while in winter diurnal activity predominates the ratio being $1.1-1.4$ (Table 5). Seasonal variation occurs more distinctly in feeding activity, as it is more defined than locomotor activity, which includes movements of various kinds made by the animals.

Table 5

\begin{tabular}{|c|c|c|c|c|}
\hline \multirow[t]{2}{*}{ Season } & \multicolumn{2}{|c|}{ Feeding } & \multicolumn{2}{|c|}{ Locomotor } \\
\hline & 1 & 2 & 1 & 2 \\
\hline Summer & 0.5 & & 0.6 & \\
\hline Autumn & 0.8 & & 0.8 & \\
\hline Winter & 1.1 & & 1.4 & \\
\hline Pre-spring, 1971 & 0.9 & & 0.7 & \\
\hline Spring & 0.6 & 0.8 & 0.7 & 0.5 \\
\hline
\end{tabular}

Table 6

Ratio of day to night activity of $S$. araneus, expressed in quotient of average number of transits per hour of day and night, depending on animals' age and sex (data from outdoor conditions).

\begin{tabular}{|c|c|c|c|c|c|c|c|c|}
\hline \multirow[b]{2}{*}{ Season } & \multicolumn{4}{|c|}{ Feeding activity } & \multicolumn{4}{|c|}{ Locomotor activity } \\
\hline & $\begin{array}{l}\text { Young } \\
\text { 우 } 9\end{array}$ & $\begin{array}{l}\text { adult } \\
\sigma^{1} \sigma^{\pi}\end{array}$ & $\begin{array}{l}\text { Old } \\
\text { 우 }\end{array}$ & $\begin{array}{l}\text { adult } \\
0^{\circ} \sigma^{\circ}\end{array}$ & $\begin{array}{l}\text { Young } \\
\text { } \$\end{array}$ & $\begin{array}{l}\text { adult } \\
\sigma^{7} \sigma^{x}\end{array}$ & $\begin{array}{l}\text { Old } \\
\text { †ㅇ }\end{array}$ & $\begin{array}{l}\text { adult } \\
\qquad \sigma^{\pi} \sigma^{*}\end{array}$ \\
\hline Summer & 0.7 & 0.7 & 0.7 & 0.4 & 0.6 & 0.4 & 0.9 & 0.6 \\
\hline Autumn & 0.7 & 0.7 & 1.2 & & 0.9 & 0.8 & 0.8 & \\
\hline Winter & 0.4 & 1.0 & & & 0.7 & 1.2 & & \\
\hline Pre-spring, 1971 & & & 1.1 & 0.8 & & & 1.1 & 0.7 \\
\hline Spring & & & 1.2 & 0.5 & & & 0.9 & 0.6 \\
\hline
\end{tabular}

Differences in the distribution of daily activity, particularly of locomotor activity, during the day and night, are also observed between different age groups of shrews at the same time of the year (Table 6). Young adult males kept outdoors are most active during the night hours in summer. Young adult females and old adult males are less active. Males in general exhibit more nocturnal activity than females, as shown by the ratio of day to night activity for successive seasons (Table 6). The 
same situation is observed in relation to feeding activity. In summer, however, all shrews, except old adult males, which exhibit greater activity during the night hours, are characterized by the same ratio of day to night feeding activity.

\section{RATIO OF LOCOMOTOR TO FEEDING ACTIVITY IN S. ARANEUS}

In all seasons of the year, except winter and pre-spring, outdoors, locomotor activity is about $30 \%$ higher than feeding activity. Conversely in winter feeding activity is $47 \%$ greater than locomotor activity (cf. Table 2). It would appear that at the colder time of the year, in a relatively large cage and with lower air temperatures than in a natural habitat, the shrews are mainly concerned with satisfying their food requirements. In pre-spring season feeding activity exceeds their locomotor activity by about $130 \%$ (cf. data in table 2 ).

Effort was made to check to what extent the given type of activity affects the level of the other forms of activity of shrews. The correlation coefficient of locomotor and feeding activity for males and females observed outdoors was respectively $r=0.55$ and $r=0.57$. It is only in certain age groups, e.g. in old adult males from summer, that it was higher $(r=0.81)$. It was found in this connection that with a very high level of one of the types of activity this correlation becomes negative. As an example of this, the correlation coefficient for a group of young adults males from summer and old adult males from spring and summer, with a high level of either feeding or locomotor activity was $r=-0.68$.

\section{ACTIVITY OF S. MINUTUS, N. ANOMALUS AND N. FODIENS IN WINTER AND SPRING}

It can be seen from the data obtained that in all the species of shrews studied outdoors the animals' activity is lower in winter than in spring (Table 7). The difference between average sums of daily activity of both types for winter and spring for $S$. minutus and males of $N$. fodiens proved to be statistically significant $(\mathrm{P}<0.05)$. At the same time considerable differences were found between the activity of males and females, within the same season. Males as a rule exhibit a lower level of activity than females, and on this account data are given separately for the two sexes for the two species of water shrew (Table 7). Considerable individual variation is found in the activity of the various groups considered, as was the case with $S$. araneus (Table 7 ).

In winter locomotor and feeding activity of females of $S$. minutus and one female of $N$. anomalus exhibit a higher level in relation to the 


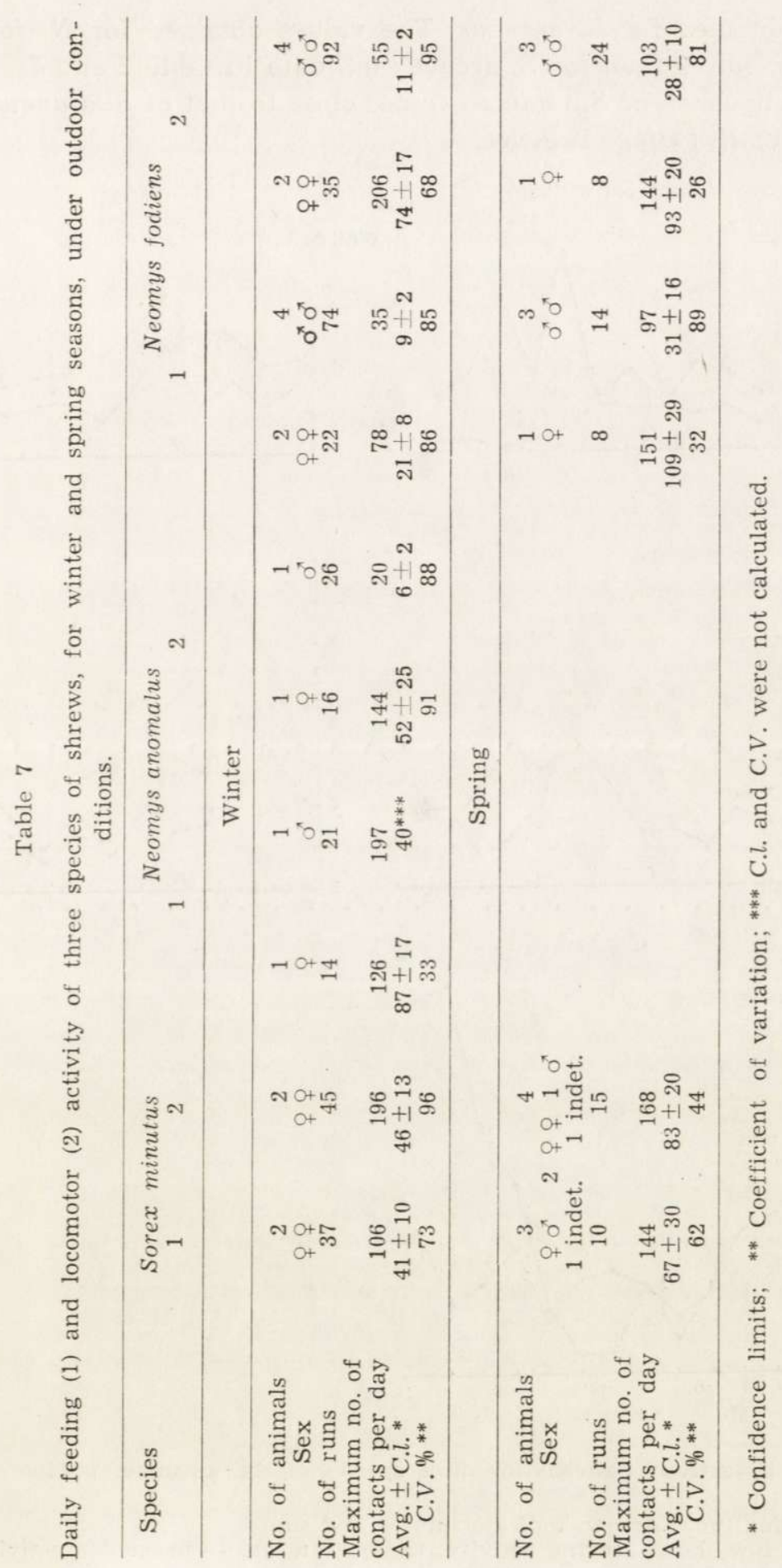


values obtained for $S$. araneus. The values obtained for $N$. fodiens are generally lower than for $S$. araneus (cf. data in table 2 and 7 ). In spring the activity level of $S$. minutus comes close to that of $S$. araneus, but the activity of $N$. fodiens is lower.

S. minutus
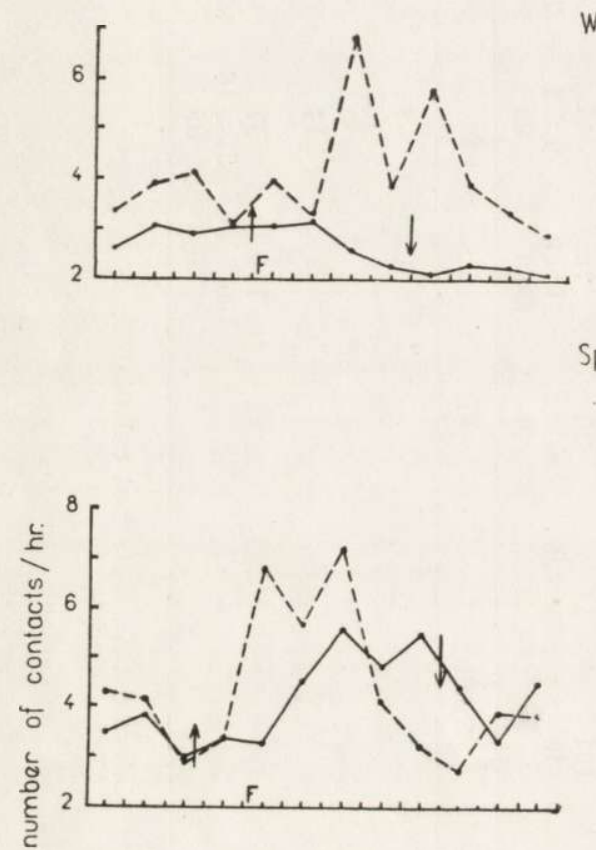

安

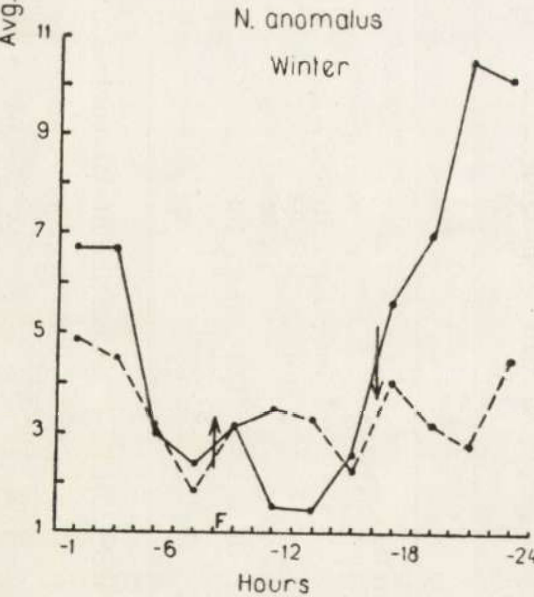

N. fodiens

Winter

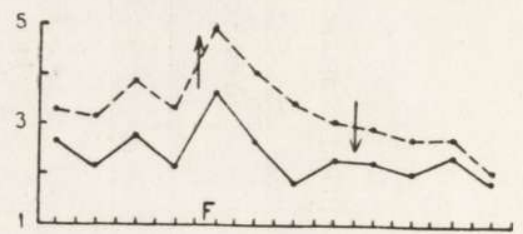

Spring

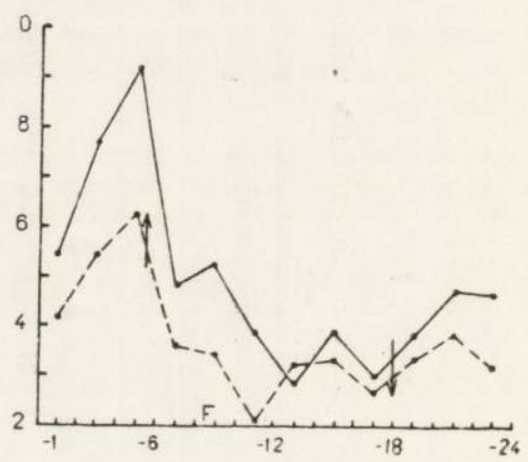

Fig. 3. Daily activity patterns for three species of shrews under outdoor conditions.

$\mathrm{F}$ - feeding time; Arrows indicate sunrise and sunset.

The solid line shows feeding activity; the broken one - locomotor activity. 
The daily activity pattern for all three species mentioned above exhibits intensified activity during the winter day (Fig. 3). Differences between species of shrews in the quotient of the average number of contacts per hour during the day and at night are slight (Table 8). The species least active during the day is $N$. anomalus, which is also shown by its daily activity pattern (Fig. 3 - feeding activity). In spring $S$. minutus exhibit a high activity level during the daytime hours, whereas $N$. fodiens changes, in a way similar to that observed in $S$. araneus, to a more nocturnal way of life (Fig. 3, Table 8).

The daily activity patterns of $S$. minutus and $N$. fodiens, in relation to which a larger amount of data were available, exhibit certain differences. In winter $S$. minutus exhibits generally intensified feeding activity during the first half of the day, without any distinct peaks; $N$. fodiens exhibits a higher, almost even, level of activity throughout the whole

Table 8

Ratio of day to night activity, for winter and spring seasons, under outdoor conditions, expressed in quotient of average number of transits per hour of day and night.

\begin{tabular}{lcccc}
\hline \multirow{2}{*}{ Species } & \multicolumn{2}{c}{ Feeding activity } & \multicolumn{2}{c}{ Locomotor activity } \\
\cline { 2 - 5 } & Winter & Spring & Winter & Spring \\
\hline Sorex minutus & 1.1 & 1.1 & 1.2 & 1.7 \\
Neomys anomalus & 0.9 & & 0.8 & \\
Neomys fodiens & 1.2 & 0.7 & 1.4 & 0.7 \\
\hline
\end{tabular}

24-hour period. The curve illustrating the locomotor activity of $S$. minutus (Fig. 3) has three peaks: the highest at about 1 p.m., the next about 5 p.m. and a third one, almost twice smaller than the first, between $3-5$ a.m. The locomotor activity of $N$. fodiens is characterized by one small peak about 5 a.m. and gradual decrease in activity from feeding time until midnight.

In spring the activity pattern of $S$. minutus and $N$. fodiens exhibits one peak. Intensification of activity of both type occurs, in the case of S. minutus, between the hours of 11 a.m. and 6 p.m. for feeding activity and for locomotor activity from 12 a.m. to 2 p.m. During the hours of dawn there is a decrease in the animals' activity and its increase after dusk does not occur until about midnight for feeding activity and about 9 p.m. to 3 a.m. for locomotor activity. In the case of $N$. fodiens maximum of activity takes place with both types of activity between 1 and 5 a.m., increase in activity being observed directly after sunset. During the day 
there is a slight increase in activity level between 2 and 4 p.m. for feeding activity and between 1 and 4 p.m. for locomotor activity.

Feeding time is always a period of increase in the animals' activity, as was observed in S. araneus. Visual observations showed that freshly supplied food is of considerable attraction to all the shrews. The animals rapidly approached the feeding box, immediately began eating and returned to the food several times.

The amplitude of activity is from two to three times greater in spring than in winter, only the amplitude of locomotor activity in S. minutus being practically the same in both seasons.

Average values for activity of both types in S. minutus and $N$. fodiens scarcely differ from each other in winter, there being a slight predominance of locomotor activity. In $N$. anomalus feeding activity is on a higher level that that of locomotor activity. In spring differences in average values for $S$. minutus are about $19 \%$ greater for locomotor activity, and for $N$. fodiens about $25 \%$ greater for feeding activity.

\section{DISCUSSION}

A conventional division of shrews' activity into feeding and locomotor activity has been accepted in this study. In order to enter the feeding box a shrew had of course to leave its nest, and thus there are certain elements of locomotor activity included in feeding activity. It was found, however, on the basis of observations of animals in cages, that shrews frequently emerged from the nest into the run and returned to the nest, without entering the feeding box. Similarly they might frequently pass by the contact recording entry into the feeding box from the run, without returning to the nest each time. It was impossible to draw an exact line of demarcation between the two types of activity, but despite this reservation their segregation proved to be interesting. The form of activity termed feeding activity related to a more defined kind of activity, while locomotor activity recorded the general activity of the animals.

The level of activity illustrated by the average sums for 24-hours (Table 2, 3, 7), and daily activity rhythm (Fig. 2, 3) were undoubtedly affected by the experimental conditions, among which were the kind of food and feeding system for these animals. The feeding system created an addition and constantly occurring peak of activity connected with feeding time. Food supplied ad libitum, easily accessible throughout the whole 24-hour period, also formed a fundamental departure from natural food, which is undoubtedly more difficult to obtain. 
The general pattern of seasonal variations in activity is the same outdoors and indoors (cf. Table 3). This shows that although the variations observed were subject to the experimental conditions they were not the result of these conditions.

The data obtained also exhibit a considerable degree of agreement with the rhythm of seasonal variations in activity found under field conditions. Comparison of daily activity patterns shows that intensification of the shrews' activity outdoors, at night, in spring and summer, with a single-peak activity pattern, agrees with the observations of J a nský \& Hanák (1960). These authors found, on the basis of the number of captures made during a 24-hour period, that there is one very clearly distinguished peak of activity at night in summer (May-July), and in spring and autumn two peaks of activity: the first - the lower of the two, in the evening and the second, higher than the first, in the hours of dawn. The activity pattern of $S$. araneus outdoors exhibits several peaks in autumn. It differed from the type of activity found under field conditions in respect of a certain shift in time of the peaks and intensification of activity in daytime hours also. The general character of seasonal variations in the activity rhythm, however, remain in agreement with those observed under field conditions.

Both outdoors, and even more so indoors, shrews exhibit considerable general activity (Table 2 and 3). Under natural conditions the high metabolic level conditions the high daily activity of shrews, which is understandable in view of their considerable food requirements. Under laboratory conditions, for instance, activity within the nest itself is connected, in T u pikova's opinion (1949) with the persistence in captivity of the behaviour pattern dictating constant penetration of the area in search for food in all the hiding-places accessible to the animals.

A relation was found between activity level and age and sex of the animals which, on account of considerable individual variation and amount of material, proved possible to illustrate in greater detail for the summer season. Young adult males, outdoors, were more active during the night hours, and exhibited far greater activity than young adult females and old adults of both sexes (Table 6, Fig. 2). This agrees with Gębczyński's observations (1965) which showed that during this period young adult individuals of $S$. araneus are more active than old adults and that the greater part of their activity occurs at night. These differences related to locomotor activity, since the average daily sums of feeding activity for young adult animals and old adults outdoors were practically the same.

The daily activity pattern for $S$. araneus shows that this shrew is more of a nocturnal animal. At all seasons of the year dusk was a distinct 
stimulus to increased activity, as has also been emphasised by Gę bc zyński (1965). With generally increased activity, however, part of the activity during the season when nights are short occurred in the daytime in animals kept outdoors (Fig. 2). In outdoor animals during autumn and winter the percentage of activity increased for the daytime hours, as shown by the ratio of average numbers of transits per hour of day and night (Table 5 and 6). Crow croft (1954) found a similar shift in the part of activity to the daytime hours when he studied the activity of $S$. aarneus under autumn conditions artificially created in a laboratory. The activity pattern revealed the occurrence of two peaks, the lower of which occurred during the day.

The activity pattern of $N$. fodiens exhibits some characters similar to that of $S$. araneus. In winter it is not very varied during the 24-hour period (particularly in respect of locomotor activity), and a large part of activity occurs during the day (Fig. 3, Table 8). The data obtained confirm the results of Gębczyńska \& Gębczyński (1965) who observed only one peak of activity to occur during the final hours of night, and a slight amplitude of activity only.

The lesser shrew is at least as active, or even more so, during the day in winter than the common shrew or water shrew (cf. tables 5 and 8). When observing the daily activity rhythm of a single individual of $S$. minutus Crowcroft (1954) found that it was generally similar to the rhythm observed in $S$. araneus, but that the chief peak of activity occurs during the "day". A different daily activity was observed in S. minutus by Gębczyński (1971). The shrews were active throughout the whole 24-hour period, with a slight predominance of night over day activity. Minimum activity occurring during day hours was observed even in winter, when no peak of activity could be observed during the other times of the day.

In spring there was an abrupt increase in activity in all the species observed outdoors. The daily activity patterns of $S$. araneus and N. fodiens indicate that the animals change to a great extent to nocturnal activity (Fig. 2, 3; Table 5 and 8). There is still a distinct predominance of day over night activity in S. minutus (Fig. 3, Table 8).

When comparing the activity of $S$. araneus, $S$. minutus, $N$. fodiens and Crocidura suaveolens Pall., T u pikova (1949) found that these animals were all uniformly active at night, the greatest daytime activity being exibited by the lesser shrew, the least by the European water shrew and intermediate by the common shrew. Tupikova (1949) concludes from this that the smaller the animal, the more active it is koth day and night. This is directly due to the high level of metabolism of shrews and the necessity for consuming food frequently, and also, 
in the Tupikova's opinion, to the fact that shrews of the genus Sorex and Neomys are unspecialized predators and require an appropriately long time to catch their prey.

The daily activity pattern of $S$. araneus outdoors exhibits seasonel variation and also certain changes connected with the animals' age. The occurrence of seasonal changes in the character of the activity pattern of $S$. araneus was also found by $\mathrm{Gębczyński}$ (1965). In winter, despite certain differences, the type of pattern was the same as in autumn and spring, and in summer despite the activity pattern appearing to be of the same type - old adults were markedly less active than young adult individuals, which was also observed outdoors in relation to locomotor activity (cf. Fig. 2).

Seasonal changes relate not only to the daily activity pattern, but also to activity level measured by average daily sums. The seasonal variation observed is in agreement with the changes taking place in the circadian metabolism rate of shrews (G ę bczyński, 1965), which was also reflected in changes in activity level, particularly locomotor activity.

Variations in the amplitude of daily activity of $S$. araneus are interesting. In relation to locomotor activity they were in agreement with seasonal changes in the sum total of daily activity. Amplitude was smallest in winter, greatest in spring and in summer slightly smaller than in spring. Shrews beginning reproduction in spring exhibited the greatest amplitude of feeding activity. Amplitude of activity was about $50 \%$ less in summer and winter, and during the transitional seasons, pre-spring and autumn, about twice smaller than in winter and summer. The decrease in activity in winter applies both to the shrews' general activity and to feeding activity, but in the former it formed $85 \%$ and in the latter $67 \%$ in relation to the summer level. Thus with a general decrease in activity feeding activity also decreases, but to a lesser degree than locomotor activity. This points to the maintenance of high food requirements in winter and to their satisfaction at the expense of a greater decrease in general activity. This fact is borne out in observations on variations in stomach weight in Sorex. It is a known fact that the weight and size of this organ are not subject to winter depression and its index (in percentages of body weight) increases during this period, and in consequence makes it possible for the animal to obtain a far larger amount of food per unit of body weight ( $\mathrm{M} \mathrm{y} \mathrm{ch} \mathrm{a}$, 1967). The variations in activity level observed also point to the maintenance under winter conditions of the system permitting of satisfying the greater food requirements during this period.

The seasonal and age variations in shrews' activity discussed above 
undoubtedly also reflect variations taking place in the morphological and physiological state of the organisms. These changes are manifested in the characteristic seasonal changes in the weight of internal organs and of the whole body in shrews ( $\mathrm{P} \mathrm{u} \mathrm{c} \mathrm{e} \mathrm{k,} \mathrm{1970)} \mathrm{and} \mathrm{exhibit} \mathrm{connection}$ not only with the season but also with the animals' age. Similarly when considering variations in shrews' activity it was impossible to treat the effect of these two factors separately.

\section{REFERENCES}

1. Coulianos C. C. \& Johnels A. G., 1962: Note on the subnivean environment of small mamals. Ark. Zool., 15, 24: 363-370.

2. Crowcroft P., 1954: The daly cycle of activity in British shrews. Proc. zool. Soc. Lond., 123: 715-729.

3. Crowcroft P., 1959: A simple technique for studying activity rhythms of small mammals by direct observation. Acta theriol., 3, 7: 105-111.

4. Gębczyński M., 1965: Seasonal and age changes of the metabolism and activity of Sorex araneus Linnaeus, 1758. Acta theriol., 10, 22: 303-331.

5. Gębczyński M., 1971: The rate of metabolism of the Lesser shrew. Acta theriol., 16, 20: $329-340$.

6. Gębczyńska Z. \& Gębczyński M., 1965: Oxygen consumption in two species of water shrews. Acta theriol., 10, 13: 209-214.

7. Janský L. \& Hanák V., 1960: Aktivität der Spitzmäuse unter natürlich Bedingungen. Säugetierkdl. Mitt., 8, 1/2: 55-63.

8. Myrcha A., 1967: Comparative studies on the morphology of the stomach in the Insectivora. Acta theriol., 12, 14: 223-244.

9. Pucek Z., 1970: Seasonal and age changes in shrews as an adaptive process. Symp. zool. Soc. Lond., 26: 189-203.

10. Tupikova I. V., 1949: Pitanie i harakter sutočnoj aktivnosti zemleroek srednej polosy SSSR. Zool. Žurn., 28, 6: 561-572.

Accepted, March 7, 1972.

Mammals Research Institute, Polish Academy of Sciences,

Białowieża, Poland.

\section{Anna BUCHALCZYK}

\section{SEZONOWE ZMIANY AKTYWNOŚCI RYJÓWEK}

\section{Streszczenie}

Badano aktywność ruchową ryjówek odłowionych w terenie i trzymanych w warunkach półnaturalnych, w klatkach na dworze (48 Sorex araneus, 5 Sorex minutus, 2 Neomys anomalus i 6 Neomys fodiens) lub w warunkach hodowlanych (32 osob- 
niki S. araneus). Wyróżniono aktywność lokomotoryczną mierzoną ilością wyjść z gniazda na wybieg i aktywność pokarmową mierzoną ilością wejść do karmnika w ciągu doby (Ryc. 1). Aktywność rejestrowano na poligrafie Jacquet'a, na kimografie (typ RP-3) lub na licznikach telefonicznych (Tabela 1).

Obserwacje na $S$. araneus obejmowaly pełny cykl roczny. Ryjówki charakteryzują się dużą zmiennością indywidualną (wartości C.V.) co powoduje występowanie znacznych różnic w poziomie aktywności zwierząt należących do tej samej płci i grupy wiekowej w danym sezonie. Aktywność ryjówek, mierzona średnimi sumami dobowymi ilości przejść, podlega zmienności sezonowej a także wykazuje pewne różnice związane $\mathrm{z}$ wiekiem i płcią zwierząt. Młode $S$. araneus w sezonie letnim mają poziom aktywności lokomotorycznej wyższy o $83 \%$ niż przeimki, przy jednakowym u obu grup poziomie aktywności pokarmowej. Jesienią ruchliwość ryjówek spada co pogłębia się jeszcze w okresie zimowym. Wiosną, następuje gwałtowny wzrost aktywnośçi (Tabela 2), co obserwowano również u S. minutus i $N$. fodiens (Tabela 7). Latem, aktywność przezimków pozostaje na poziomie wiosennym lub nieznacznie wzrasta (Tabela 2). Różnice pomiędzy średnimi sumami aktywności dobowej w poszczególnych sezonach roku są statystycznie istotne, za wyjątkiem różnicy w aktywności przezimków wiosną i latem.

Zmienność aktywności $S$. araneus w warunkach hodowlanych przebiega podobnie jak w warunkach półnaturalnych (Tabela 2),

$\mathrm{Na}$ przykładzie sezonu letniego stwierdzono, że młode samce mają wyraźnie wyższe sumy aktywności dobowej niż młode samice i przezimki obu płci i są aktywniejsze $\mathrm{w}$ godzinach nocy niż osobniki z pozostałych grup (Tabela 3,5 i 6).

Wzorzec aktywności dobowej $S$. araneus zmienia się zależnie od sezonu roku. Latem i wiosną jest jednoszczytowy, z nasileniem aktywności nocą. Jednakże u osobników młodych, aktywniejszych niż przezimki część aktywności lokomotorycznej latem, przypada również na godziny dnia (Ryc. 2). Jesienią i zimą wzrasta poziom aktywności przypadającej na godziny dzienne i wzorzec aktywności staje się co najmniej dwuszczytowy (Ryc. 2, Tabela 5). U S. minutus obserwuje się nasilenie aktywności w godzinach dnia także i w sezonie wiosennym, podczas gdy wzorzec aktywności dobowej $N$. fodiens wiosną, jest zbliżony do obserwowanego u $S$. araneus (Ryc. 3, Tabela 8).

Amplituda aktywności dobowej $S$. araneus, wyrażona procentową różnicą między minimalną a maksymalną średnią ilością kontaktów na godzinę w ciągu doby, przy aktywności lokomotorycznej jest zgodna $\mathrm{z}$ sezonowymi zmianami aktywności dobowej. Przy aktywności pokarmowej największą amplitudę obserwuje się w aktywności ryjówek rozpoczynających rozród - wiosną; mniejszą od tej o około $50 \%$ w okresie zimowym i letnim a na przedwiośniu i jesienią (w sezonach przejściowych) około dwa razy mniejszą niż zimą i latem (Tabela 4). 